\title{
Serological Cross-Reactivity between Different Chlamydia-Like Organisms ${ }^{\nabla}$
}

\author{
Nicola Casson, ${ }^{1}$ José M. Entenza, ${ }^{2}$ and Gilbert Greub ${ }^{1 *}$ \\ Center for Research on Intracellular Bacteria, Institute of Microbiology, ${ }^{1}$ and Department of Fundamental Microbiology, ${ }^{2}$ \\ University of Lausanne, Lausanne, Switzerland
}

Received 8 September 2006/Accepted 12 October 2006

\begin{abstract}
The serological cross-reactivity between different recently described Chlamydia-related organisms was determined. Mouse sera exhibited a strong reactivity against autologous antigen and closely related heterologous antigen but no cross-reactivity with distantly related species. These results are important to better interpret serological studies and assess the pathogenic role of these obligate intracellular bacteria.
\end{abstract}

New Chlamydia-related species have been isolated and assigned to the Chlamydiales order (8), including Parachlamydia acanthamoebae (1), Simkania negevensis (16), Neochlamydia hartmannellae (14), Waddlia chondrophila (22), Protochlamydia amoebophila (3), Criblamydia sequanensis (23), and Rhabdochlamydia crassificans (5). Serological studies have suggested that some of these intracellular bacteria may cause respiratory tract infections in humans. $P$. acanthamoebae antibody reactivity was documented in patients with community-acquired pneumonia $(2,21)$ and aspiration pneumonia (11). Enzymelinked immunosorbent assay suggested a possible role of Simkania negevensis in acute respiratory infections (20), in exacerbation of chronic obstructive pulmonary disease (19) and in community-acquired pneumonia in children (6). Since microimmunofluorescence is the gold standard method for the diagnosis of infection due to Chlamydiaceae (7) and Chlamydia-like organisms (4), we used this technique to define the level of crossreactivity between the different bacterial species. The molecular weights of immunogenic proteins were also determined by Western blotting. Moreover, we inferred a serological differentiation index (SDI) phyletic tree $(9,24)$ and compared its topology to that of the 16S rRNA phylogenetic tree.

Chlamydia-like organisms grown using amoebal coculture $(12,13)$ and purified on sucrose barrier were used as antigens to immunize mice. Acanthamoeba castellanii (ATCC 30010) was used to grow $P$. acanthamoebae strain BN9 (ATCC VR1476), $P$. acanthamoebae strain Hall's coccus, $P$. amoebophila strain UWE25 (ATCC PRA-7), S. negevensis (ATCC VR-1471), W. chondrophila (ATCC 1470), C. sequanensis (CRIB-18), and $R$. crassificans (CRIB-01). Hartmannella vermiformis strain BL was used to grow N. hartmannellae (ATCC 50802). Purified bacteria were injected intravenously to 6-week-old BALB/c mice (two mice per antigen). After four immunizations, blood was collected, and sera were obtained by centrifugation at $5,200 \times g$ for $5 \mathrm{~min}$ at $4^{\circ} \mathrm{C}$. Twofold-diluted sera were tested by immunofluorescence for antibody reactivity against purified antigens. Fluorescein isothiocyanate-coupled anti-mouse immunoglobulin antibody (Bio-Rad, Rheinach, Switzerland) was

\footnotetext{
* Corresponding author. Mailing address: Center for Research on Intracellular Bacteria, Institute of Microbiology, University of Lausanne, 1011 Lausanne, Switzerland. Phone: 4121/314.49.79. Fax: 4121/ 314.40.60. E-mail: gilbert.greub@chuv.ch.

${ }^{\nabla}$ Published ahead of print on 25 October 2006
}

used as a secondary antibody. Phosphate-buffered saline-milk and uninfected axenic $A$. castellanii (ATCC 30010) were used as negative controls. The IgG/IgM Micro-IF test kit (ANILabsystems, Vantaa, Finland) was used to test the antibody reactivity of mice sera against Chlamydia trachomatis, Chlamydophila psitacci, and Chlamydophila pneumoniae antigens.

Mice responded adequately to injected antigens. Very high titers of 1/32,768 and 1/16,384 were obtained after immunization with $W$. chondrophila and $P$. acanthamoebae strain Hall's coccus, respectively. Similar results were obtained for each duplicate sera, with titers varying by less than one dilution. Sera elicited against any of all Chlamydia-like organisms tested did not exhibit cross-reactivity against amoeba. The serological cross-reactivity (SDI) between two bacteria, expressed as the number of twofold dilution steps separating homologous and heterologous titers, were calculated as described previously (9). Table 1 shows antibody titers and SDIs obtained from reciprocal cross-reactions of mouse antisera with different Chlamydia-like organisms, as determined by immunofluorescence. Significant cross-reactivity was observed between closely related species, for instance, between the $P$. amoebophila and $P$. acanthamoebae strains. In contrast, no or little cross-reactivity was detected between distantly related Chlamydia-like organisms. No cross-reactivity against C. pneumoniae, C. trachomatis, and $C$. psittaci was detected when we tested sera elicited with any Chlamydia-like organisms, except $P$. acanthamoebae strain Hall's coccus that reacted with $C$. pneumoniae (titer of 1/128). A tree inferred from SDIs was built by using the neighbor-joining option of the PHYLIP software (10). 16S rRNA sequences were used to infer another neighbor-joining tree (see Fig. 1A for the GenBank accession numbers), using Kimura-corrected p-distance and the complete deletion option of the MEGA software (18). Both SDI and 16S rRNA-based trees were rooted using $W$. chondrophila as an outgroup. The phyletic tree based on the SDI was congruent with the tree inferred from 16S rRNA encoding gene sequences (Fig. 1A). This suggests that cross-reactivity between members of the Chlamydiales order is proportional to the level of relatedness between each species, i.e., to the likeliness of common epitopes.

To determine the molecular weight of immunogenic proteins of Chlamydia-like organisms, Western blots were performed as described previously (11). The membrane was first incubated with the mouse serum diluted 1/64. After washing steps, the membrane was further incubated with a 1/500 dilu- 
TABLE 1. Antibody titers and SDIs obtained from reciprocal cross-reactions of mouse antisera with different Chlamydia-like organisms, as determined by immunofluorescence

\begin{tabular}{|c|c|c|c|c|c|c|c|c|}
\hline \multirow[b]{2}{*}{ Species studied } & \multicolumn{8}{|c|}{ Antibody titer (SDI) } \\
\hline & $\begin{array}{c}\text { P. acanthamoebae } \\
\text { strain BN9 }\end{array}$ & $\begin{array}{l}\text { P. acanthamoebae } \\
\text { strain Hall's } \\
\text { coccus }\end{array}$ & P. amoebophila & N. hartmannellae & R. crassificans & S. negevensis & C. sequanensis & W. chondrophila \\
\hline $\begin{array}{l}\text { P. acanthamoebae } \\
\text { strain BN9 }\end{array}$ & $1,024(0)$ & $1,024(4)$ & $128(1)$ & $32(10)$ & $<32(10)$ & $<32(11)$ & $<32(17)$ & $<32(17)$ \\
\hline $\begin{array}{l}\text { P. acanthamoebae } \\
\text { strain Hall's coccus }\end{array}$ & $1,024(4)$ & $16,384(0)$ & $512(3)$ & $64(12)$ & $<32(12)$ & $32(12)$ & $<32$ (19) & $64(19)$ \\
\hline P. amoebophila & $1,024(1)$ & $1,024(3)$ & $256(0)$ & $32(7)$ & $64(3)$ & $<32(5)$ & $128(9)$ & $64(10)$ \\
\hline N. hartmannellae & $128(10)$ & $128(12)$ & $128(7)$ & $2,048(0)$ & $<32$ (11) & $<32(12)$ & $<32(18)$ & $<32(18)$ \\
\hline R. crassificans & $32(10)$ & 64 (12) & $128(3)$ & $<32(11)$ & $256(0)$ & $64(3)$ & $256(8)$ & $64(10)$ \\
\hline S. negevensis & $<32(11)$ & $64(12)$ & $256(5)$ & $<32(12)$ & $256(3)$ & $512(0)$ & $512(8)$ & $128(12)$ \\
\hline C. sequanensis & $32(17)$ & $64(19)$ & $128(9)$ & $<32(18)$ & $128(8)$ & $128(8)$ & $32,768(0)$ & $256(13)$ \\
\hline W. chondrophila & $<32(17)$ & $<32(19)$ & $128(10)$ & $<32(18)$ & $128(10)$ & $32(12)$ & $512(13)$ & $32,768(0)$ \\
\hline
\end{tabular}

tion of a peroxidase-labeled goat anti-mouse immunoglobulin G (Bio-Rad).

P. amoebophila had immunogenic proteins of approximately 130, 70, 43, and $30 \mathrm{kDa}$. For P. acanthamoebae strain BN9, a protein of approximately $70 \mathrm{kDa}$ exhibited the strongest immunogenicity. For $N$. hartmannellae, proteins of approximately $89,70,53$, and $45 \mathrm{kDa}$ exhibited the strongest immunogenicity, whereas proteins of $W$. chondrophila of about 70, 53, 45, and 30
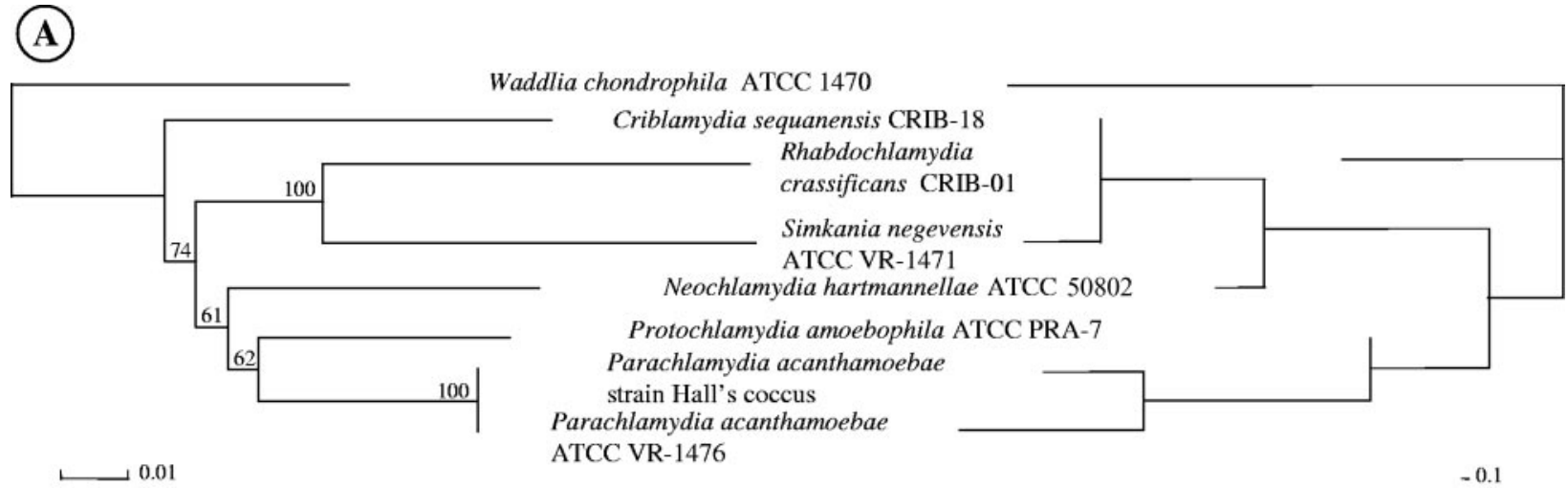

(B)

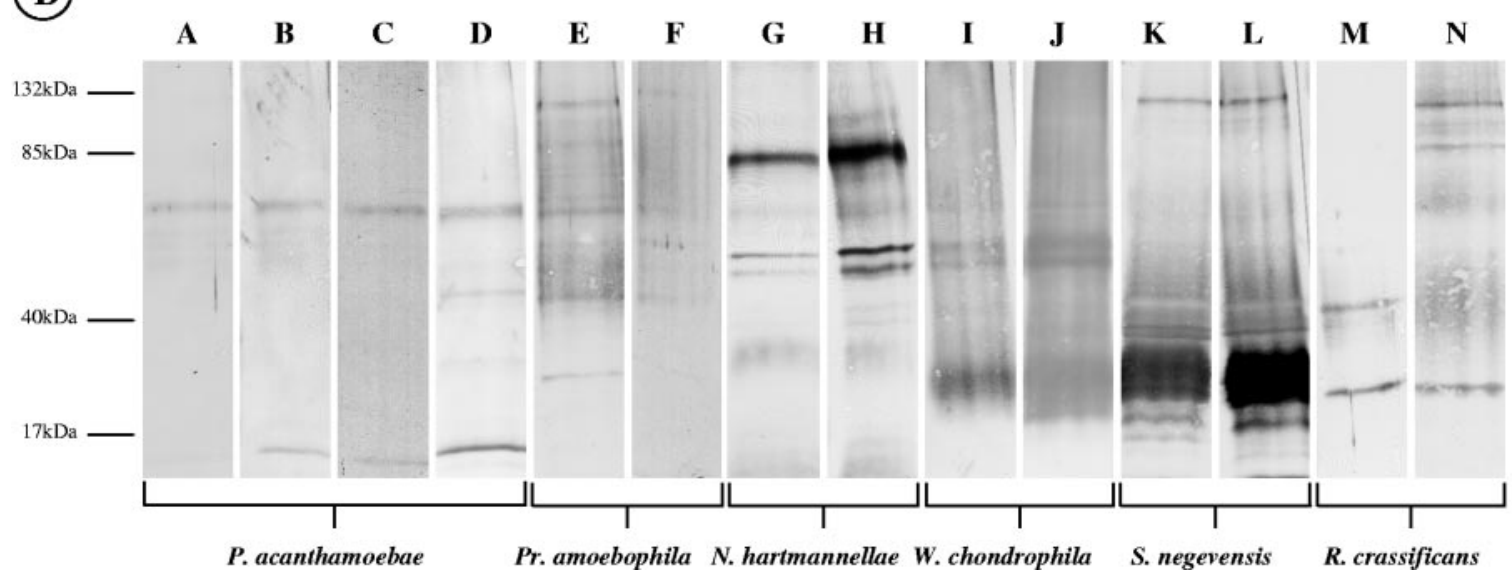

FIG. 1. (A) Congruence of the phylogenetic tree based on the 16S rRNA encoding gene (left panel) and the phyletic tree based on the SDI (right panel). Both trees were built by using the neighbor-joining method and were outrooted with Waddlia chondrophila. The 16S rRNA sequences were downloaded from GenBank. The accession numbers are as follows: Waddlia chondrophila, AF042496; Rhabdochlamydia crassificans, AY928092; Simkania negevensis, U68460; Neochlamydia hartmannellae, AF177275; Protochlamydia amoebophila, BX908798; Parachlamydia acanthamoebae strain Hall's coccus, AF366365; and Parachlamydia acanthamoebae strain BN9, Y07556. (B) Western blot pattern of each Chlamydia-like organisms. Each serum elicited in mice (two sera raised against each bacteria) was tested against its autologous antigen. All sera were tested at a 1/64 dilution. Lanes: A and B, Parachlamydia acanthamoebae strain BN9; C and D, Parachlamydia acanthamoebae strain Hall's coccus; E and F, Protochlamydia amoebophila; $\mathrm{G}$ and $\mathrm{H}$, Neochlamydia hartmannellae; I and J, Waddlia chondrophila; K and L, Simkania negevensis; M and N, Rhabdochlamydia crassificans. The molecular sizes reported on the left of the figure were determined by using the Kaleidoscope prestained marker (Bio-Rad). 
kDa exhibited the highest immunogenicity. For S. negevensis, a protein of approximately $30 \mathrm{kDa}$ exhibited the strongest immunogenicity, although having immunogenic proteins of approximately 130,35 , and $20 \mathrm{kDa}$. $R$. crassificans possess immunogenic proteins of 130, 89, 43, and $25 \mathrm{kDa}$ (Fig. 1B). Earlier, Western blot has been used to confirm immunofluorescence results in two studies investigating the role of Chlamydia-like organisms in pneumonia $(11,25)$. The first study used as a positive control a rabbit serum elicited with $P$. acanthamoebae that exhibited a strong reactivity against proteins of about 70 , 40 , and $28 \mathrm{kDa}(11)$. Here, we also identified a $70-\mathrm{kDa}$ parachlamydial immunogenic protein. In the second study, a $64-\mathrm{kD}$ a protein exhibited the strongest immunogenicity $(4,25)$.

Since serology was not discriminative at the species level for Parachlamydiaceae, previous serological studies suggesting a role of Parachlamydia as a new agent of pneumonia $(2,11,21)$ should be interpreted as a hint for a role of either Parachlamydia or Parachlamydia-related species in respiratory tract infections. Conversely, serological studies aiming at defining the pathogenicity of Simkania spp. showed a high seroprevalence. The absence of cross-reactivity between Simkania spp., Parachlamydia spp. (Table 1), and all three Chlamydiaceae tested in our study support the idea that humans are frequently exposed to Simkania spp. or cross-reacting related species. Whether Simkania spp. cause respiratory tract diseases remains to be demonstrated since Kumar et al. (17) and Johnsen et al. (15) did not confirm early studies by Lieberman et al. $(19,20)$. Discrepant results might be due to some cross-reactivity of the enzyme-linked immunosorbent assay used by Lieberman et al. with Chlamydia-like organisms such as Rhabdochlamydia that exhibit common immunogenic proteins.

In conclusion, we have described the level of cross-reactivity and the molecular weight of immunogenic proteins of Chlamydialike organisms. Understanding the pathogenic potential of Chlamydia-like organisms in humans and animals should be reconsidered using these findings.

We thank Philip Tarr (Infectious Diseases Service, University of Lausanne) for reviewing the manuscript and Ludivine Pugin (Center for Research on Intracellular Bacteria) for technical help.

This study was partially supported by Swiss National Science Foundation grant FN 3200130-105885.

\section{REFERENCES}

1. Amann, R., N. Springer, W. Schonhuber, W. Ludwig, E. N. Schmid, K. D. Muller, and R. Michel. 1997. Obligate intracellular bacterial parasites of acanthamoebae related to Chlamydia spp. Appl. Environ. Microbiol. 63:115121.

2. Birtles, R. J., T. J. Rowbotham, C. Storey, T. J. Marrie, and D. Raoult. 1997. Chlamydia-like obligate parasite of free-living amoebae. Lancet 349:925926.

3. Collingro, A., E. R. Toenshoff, M. W. Taylor, T. R. Fritsche, M. Wagner, and M. Horn. 2005. "Candidatus Protochlamydia amoebophila," an endosymbiont of Acanthamoeba spp. Int. J. Syst. Evol. Microbiol. 55:1863-1866.

4. Corsaro, D., and G. Greub. 2006. Pathogenic potential of novel Chlamydiae and diagnostic approaches to infections due to these obligate intracellular bacteria. Clin. Microbiol. Rev. 19:283-297.

5. Corsaro, D., V. Thomas, G. Goy, D. Venditti, R. Radek, and G. Greub. "Candidatus Rhabdochlamydia crassificans," an intracellular bacterial pathogen of the cockroach Blatta orientalis (Insecta: Blattodea). Syst. Appl. Microbiol., in press.
6. Don, M., M. Paldanius, L. Fasoli, M. Canciani, and M. Korppi. 2006. Simkania negevensis and pneumonia in children. Pediatr. Infect. Dis.J. 25: 470-471.

7. Dowell, S. F., R. W. Peeling, J. Boman, G. M. Carlone, B. S. Fields, J. Guarner, M. R. Hammerschlag, L. A. Jackson, C. C. Kuo, M. Maass, T. O. Messmer, D. F. Talkington, M. L. Tondella, and S. R. Zaki. 2001. Standardizing Chlamydia pneumoniae assays: recommendations from the Centers for Disease Control and Prevention (USA) and the Laboratory Centre for Disease Control (Canada). Clin. Infect. Dis. 33:492-503.

8. Everett, K. D., R. M. Bush, and A. A. Andersen. 1999. Emended description of the order Chlamydiales, proposal of Parachlamydiaceae fam. nov. and Simkaniaceae fam. nov., each containing one monotypic genus, revised taxonomy of the family Chlamydiaceae, including a new genus and five new species, and standards for the identification of organisms. Int. J. Syst. Bacteriol. 49:415-440.

9. Fang, R., and D. Raoult. 2003. Antigenic classification of Rickettsia felis by using monoclonal and polyclonal antibodies. Clin. Diagn. Lab. Immunol. 10:221-228.

10. Felsenstein, J. 1997. An alternating least squares approach to inferring phylogenies from pairwise distances. Syst. Biol. 46:101-111.

11. Greub, G., I. Boyadjiev, B. La Scola, D. Raoult, and C. Martin. 2003. Serological hint suggesting that Parachlamydiaceae are agents of pneumonia in polytraumatized intensive care patients. Ann. N. Y. Acad. Sci. 990:311319.

12. Greub, G., B. La Scola, and D. Raoult. 2004. Amoebae-resisting bacteria isolated from human nasal swabs by amoebal coculture. Emerg. Infect. Dis. 10:470-477.

13. Greub, G., and D. Raoult. 2002. Crescent bodies of Parachlamydia acanthamoeba and its life cycle within Acanthamoeba polyphaga: an electron micrograph study. Appl. Environ. Microbiol. 68:3076-3084.

14. Horn, M., M. Wagner, K. D. Muller, E. N. Schmid, T. R. Fritsche, K. H. Schleifer, and R. Michel. 2000. Neochlamydia hartmannellae gen. nov., sp. nov. (Parachlamydiaceae), an endoparasite of the amoeba Hartmannella vermiformis. Microbiology 146(Pt. 5):1231-1239.

15. Johnsen, S., N. Birkebaek, P. L. Andersen, C. Emil, J. S. Jensen, and L. Ostergaard. 2005. Indirect immunofluorescence and real-time PCR for detection of Simkania negevensis infection in Danish adults with persistent cough and in healthy controls. Scand. J. Infect. Dis. 37:251-255.

16. Kahane, S., K. D. Everett, N. Kimmel, and M. G. Friedman. 1999. Simkania negevensis strain ZT: growth, antigenic, and genome characteristics. Int. J. Syst. Bacteriol. 49:815-820.

17. Kumar, S., S. A. Kohlhoff, M. Gelling, P. M. Roblin, A. Kutlin, S. Kahane, M. G. Friedman, and M. R. Hammerschlag. 2005. Infection with Simkania negevensis in Brooklyn, New York. Pediatr. Infect. Dis. J. 24:989-992.

18. Kumar, S., K. Tamura, and M. Nei. 2004. MEGA3: integrated software for molecular evolutionary genetics analysis and sequence alignment. Brief Bioinform. 5:150-163.

19. Lieberman, D., B. Dvoskin, D. V. Lieberman, S. Kahane, and M. G. Friedman. 2002. Serological evidence of acute infection with the Chlamydia-like microorganism Simkania negevensis (Z) in acute exacerbation of chronic obstructive pulmonary disease. Eur. J. Clin. Microbiol. Infect. Dis. 21:307309.

20. Lieberman, D., S. Kahane, D. Lieberman, and M. G. Friedman. 1997. Pneumonia with serological evidence of acute infection with the Chlamydia-like microorganism "Z”. Am. J. Respir. Crit. Care Med. 156:578-582.

21. Marrie, T. J., D. Raoult, B. La Scola, R. J. Birtles, and E. de Carolis. 2001. Legionella-like and other amoebal pathogens as agents of communityacquired pneumonia. Emerg. Infect. Dis. 7:1026-1029.

22. Rurangirwa, F. R., P. M. Dilbeck, T. B. Crawford, T. C. McGuire, and T. F. McElwain. 1999. Analysis of the 16S rRNA gene of micro-organism WSU 86-1044 from an aborted bovine fetus reveals that it is a member of the order Chlamydiales: proposal of Waddliaceae fam. nov., Waddlia chondrophila gen. nov., sp. nov. Int. J. Syst. Bacteriol. 49(Pt. 2):577-581.

23. Thomas, V., N. Casson, and G. Greub. 2006. Criblamydia sequanensis, a new intracellular Chlamydiales isolated from Seine river water using amoebal coculture. Environ. Microbiol. 8:2125-2135.

24. Van Regenmortel, M. H., and M. B. von Wechmar. 1970. A reexamination of the serological relationship between tobacco mosaic virus and cucumber virus 4. Virology 41:330-338.

25. Yamaguchi, T., T. Yamazaki, M. Inoue, C. Mashida, K. Kawagoe, M. Ogawa, S. Shiga, Y. Nakagawa, T. Kishimoto, I. Kurane, K. Ouchi, and T. Ohzeki. 2005. Prevalence of antibodies against Simkania negevensis in a healthy Japanese population determined by the microimmunofluorescence test. FEMS Immunol. Med. Microbiol. 43:21-27. 